\title{
Kenal Saja Tidak Cukup: Eksplorasi Motif dan Bentuk Pertemanan Urban
}

\author{
Egi Prawita \\ Center for Indigenous and Cultural Psychology, Fakultas Psikologi, Universitas Gadjah Mada \\ Jl. Humaniora 1 Bulaksumur, Sleman, Yogyakarta 55281, Indonesia \\ egiprawita@mail.ugm.ac.id \\ Arka Nareswari \\ Center for Indigenous and Cultural Psychology, Fakultas Psikologi, Universitas Gadjah Mada \\ Jl. Humaniora 1 Bulaksumur, Sleman, Yogyakarta 55281, Indonesia \\ arka.nareswari@mail.ugm.ac.id
}

M.Th. Asti Wulandari

Center for Indigenous and Cultural Psychology, Fakultas Psikologi, Universitas Gadjah Mada

J1. Humaniora 1 Bulaksumur, Sleman, Yogyakarta 55281, Indonesia

m.theresia.asti@mail.ugm.ac.id

F.A. Nurdiyanto

Center for Indigenous and Cultural Psychology, Fakultas Psikologi, Universitas Gadjah Mada J1. Humaniora 1 Bulaksumur, Sleman, Yogyakarta 55281, Indonesia

nurdiyanto@mail.ugm.ac.id

Infromasi Artikel

\begin{tabular}{ll}
\hline Tanggal masuk & $25-03-2020$ \\
Tanggal revisi & $27-07-2020$ \\
Tanggal diterima & $14-08-2020$
\end{tabular}

Kata Kunci:

pemuda urban;

pertemanan;

Yogyakarta
Abstrak

Pemuda urban memiliki tantangan dalam menjalin pertemanan, seiring dengan keberagaman identitas masyarakat urban. Yogyakarta merupakan daerah yang menjadi titik temu pemuda multi-identitas. Tantangan muncul bagi pemuda lokal dan pendatang untuk menjalin pertemanan. Penelitian ini bertujuan untuk menggambarkan motif dan bentuk pertemanan pada pemuda urban di Yogyakarta. Penelitian ini menggunakan metode kualitatif eksploratori. Wawancara semi-terstruktur diajukan kepada 8 pemuda (4 migran, 4 nonmigran) di Yogyakarta. Analisis tematik digunakan untuk memunculkan tema-tema motif dan bentuk pertemanan pemuda urban. Kredibilitas penelitian dilakukan dengan triangulasi peneliti. Hasil penelitian ini memunculkan 3 tema utama: 1) motif pertemanan, 2) perubahan pertimbangan memilih teman, dan 3) jenis pertemanan. Motif pertemanan di antaranya kesamaan gaya komunikasi, iklim suportif, proksimitas, dan terpenuhinya kebutuhankebutuhan. Perubahan pertimbangan dalam pertemanan didasarkan adanya untung-rugi dalam pertemanan. Jenis pertemanan yang muncul dibedakan berdasarkan keintimannya. Pemuda urban di Yogyakarta lebih menunjukkan adanya fleksibilitas dalam membentuk pertemanan yang tidak hanya terbatas pada persamaan identitas sosial.

\section{Abstract}

Urban youth has challenges in building friendships, along with the diversity of the identities of urban communities. Yogyakarta is a meeting point for multi-identity youth. Challenges arise for local youth and migrants to make friends. This study aims to explore the motives and types of friendship in urban youth in Yogyakarta. This research uses exploratory qualitative methods. Semi-structured interviews were submitted to 8 youth (4 migrants, 4 non-migrants) in Yogyakarta. Thematic analysis is used to bring up the themes of motives and forms of friendship of urban youth. The credibility of the study was carried out by investigator triangulation. The results of this study raised 3 main themes: 1) friendship motives, 2) changes in consideration of choosing friends, and 3) types of friendship. Friendship motives include the similarity of communication styles, supportive climate, proximity, and the fulfillment of needs. Changes in consideration in friendships are based on profit and loss in friendship. The types of friendships that appear are distinguished by their intimacy. Urban youth in Yogyakarta show more flexibility in forming friendships that are not limited to social identity. 


\section{PENDAHULUAN}

Relasi pertemanan merupakan bentuk interaksi sosial yang bersifat sukarela, timbal balik, dan egaliter (Rubin \& Bowker, 2018). Hubungan tersebut tidak memiliki hierarki tertentu, sehingga tindakan yang dilakukan setara satu sama lain. Pertemanan juga dapat dinilai sebagai kelompok yang dapat memberikan afek positif, kenyamanan, dan sumber dukungan emosional bagi seseorang (Kathiravelu, 2013). Hal ini diwujudkan dengan adanya kerelaan dan kebersamaan. Selain itu, memiliki hubungan yang dekat dengan orang lain dapat meningkatkan kebahagiaan dan citra diri yang positif (Nguyen et al., 2016) serta memberikan dampak positif bagi kesehatan mental individu (Tsaousis, 2016). Pertemanan yang berkualitas dapat membantu seseorang lebih terbuka dengan orang lain dan memiliki tingkat kesepian yang rendah (Corsano et al., 2017).

Relasi pertemanan juga didasarkan pada kesamaan yang dimiliki antar individu (Leszczensky \& Pink, 2015). Campbell et al. (2015) mengafirmasi bahwa pertemanan yang memiliki kesamaan cenderung merasakan kenikmatan dan penghargaan yang lebih tinggi. Kesamaan yang dimiliki berperan mempererat pertemanan dan menghindarkan hubungan dari konflik jangka Panjang (Hafen et al., 2011). Fungsi pertemanan sulit dicapai jika ketidaksamaan lebih banyak ditemukan dalam hubungan tersebut.

Hubungan pertemanan yang tidak timbal balik antar individu dapat memicu konflik interpersonal (Echols \& Graham, 2016). Ketegangan yang terjadi cenderung menimbulkan perlakuan yang tidak adil, diskriminasi, dan isolasi. Kondisi tersebut lebih terjadi pada relasi dengan identitas majemuk, seperti agama, etnisitas, atau daerah asal yang berbeda (Leszczensky \& Pink, 2015). Hal ini memungkinkan terjadinya favoritisme kelompok dan pertemanan yang eksklusif.

Daerah perkotaan sendiri memiliki tingkat keragaman identitas dan penduduk migran yang tinggi. Pendatang diharapkan memiliki kemampuan menjalin relasi di lingkungan baru. Kegagalan menjalin relasi pertemanan dapat menimbulkan permasalahan interpersonal (Killias, 2017). Kaum migran cenderung merasakan kecurigaan dan perasaan was-was menerima stigma dari penduduk lokal. Selain itu, mereka juga mengalami kesulitan beradaptasi karena pertemanan mono-etnis yang cenderung memiliki ikatan yang lebih kuat dan memungkinkan munculnya segregasi etnis (Leszczensky \& Pink, 2015). Segregasi ini dapat membahayakan relasi dan rentan muncul konflik pertemanan yang lebih besar.

Kathiravelu \& Bunnell (2017) menyatakan bahwa pertemanan juga dapat berasal dari pertemuan individu yang berbeda. Pada masyarakat urban, pertemanan dapat timbul dari perbedaan etnisitas, ras, gender, dan kelas sosial (Lobo, 2017). Perjumpaan multietnis sangat mungkin ditemui di Indonesia, karena keberagaman etnisitas dan budaya. Di Kota Yogyakarta sendiri memiliki tingkat migrasi yang tinggi. Tahun 2018 terdapat 11.923 jiwa arus masuk penduduk yang menetap di Kota Yogyakarta dan 10.586 jiwa di kabupaten lain (Hildayah, 2019). Implikasinya, Yogyakarta menjadi titik temu pemuda dengan latar belakang yang beragam. Hal ini menjadi tantangan tersendiri bagi pemuda lokal dan pendatang untuk menjalin pertemanan.

Masyarakat Yogyakarta merupakan masyarakat Jawa yang identik dengan kultur kolektif. Relasi pertemanan yang mencolok dalam kultur kolektif adalah memiliki ikatan pertemanan yang intim (Triandis, 2018). Semakin dalam ikatan yang dibangun, semakin besar usaha berteman yang rela dikeluarkan. Sejalan dengan Clark \& Mills (2012) yang menyatakan bahwa pada hubungan dengan tingkat intimasi tertentu, relasi pertemanan tidak dirasakan sebagai beban untuk melakukan sesuatu yang setimpal. Meskipun kental dengan kultur kolektif, namun tidak dapat dipungkiri Yogyakarta adalah daerah urban dengan bentuk pertemanan berdasarkan pertukaran sosial. Alih-alih dekat secara intim, individu 
memiliki relasi untuk saling memenuhi kebutuhan dan transaksional (Kathiravelu \& Bunnell, 2017).

Berdasarkan uraian di atas, penelitian ini dilakukan untuk menggambarkan motif dan bentuk pertemanan pada pemuda urban di Yogyakarta, sehingga dapat menjadi dasar akademik untuk menilik faktor-faktor penguat persatuan di daerah multi-identitas. Kemudian dikerucutkan ke dalam pertanyaan penelitian 1) apa yang membuat pemuda urban menjalin pertemanan, dan 2) pertemanan seperti apa yang dimiliki pemuda urban?

\section{METODE}

Metode yang digunakan dalam penelitian ini adalah kualitatif eksploratori. Pendekatan ini digunakan untuk menggali motif dan bentuk pertemanan pada pemuda urban. Penelitian ini dilakukan di Yogyakarta pada Maret-Juli 2019. Kriteria responden yang ditetapkan dalam penelitian ini adalah: 1) pemuda yang berusia 19-29 tahun, 2) partisipan migran berasal dari daerah urban di Jabodetabek) yang telah tinggal di Yogyakarta sekurangkurangnya 1 tahun, dan 3) partisipan nonmigran yang tinggal di daerah urban di Yogyakarta. Karakteristik partisipan yang terlibat dalam penelitian disajikan dalam tabel 1 .

Data diperoleh melalui wawancara semiterstruktur. Masing-masing partisipan diwawancara sebanyak 2 kali pertemuan selama kurang lebih 1-2 jam. Panduan wawancara disusun berdasarkan tujuan penelitian untuk menggambarkan motif dan bentuk pertemanan pemuda urban. Misalnya, 1) Apa yang membuat Anda memilih berteman dengan seseorang atau sekelompok orang? Mengapa? 2) Sejauh mana Anda memiliki jenis pertemanan yang berbeda?

Analisis tematik digunakan untuk memungkinkan munculnya tema-tema motif dan bentuk pertemanan. Proses dilakukan dalam beberapa langkah sesuai dengan yang dikemukakan oleh Braun dan Clarke (2006), yaitu 1) mengenal data hasil penelitian, 2) melakukan initial codes 3) mencari tematema yang sesuai 4) melihat kesesuaian
Tabel 1.

Karakteristik Partisipan

\begin{tabular}{|c|c|c|c|}
\hline Partisipan & $\begin{array}{c}\text { Usia } \\
\text { (tahun) }\end{array}$ & $\begin{array}{c}\text { Jenis } \\
\text { Kelamin }\end{array}$ & $\begin{array}{c}\text { Daerah Asal } \\
\text { (Migran/ } \\
\text { Non-migran) }\end{array}$ \\
\hline P1 & 26 & Perempuan & $\begin{array}{c}\text { Tangerang } \\
\text { (Migran) }\end{array}$ \\
\hline P2 & 29 & Perempuan & $\begin{array}{c}\text { Bogor } \\
\text { (Migran) }\end{array}$ \\
\hline P4 & 20 & Laki-laki & $\begin{array}{c}\text { Jakarta } \\
\text { (Migran) }\end{array}$ \\
\hline P5 & 20 & Laki-laki & $\begin{array}{c}\text { Yogyakarta } \\
\text { (Non- } \\
\text { Migran) }\end{array}$ \\
\hline P6 & 27 & Laki-laki & $\begin{array}{c}\text { Yogyakarta } \\
\text { (Non- } \\
\text { Migran) }\end{array}$ \\
\hline P7 & 19 & Perempuan & $\begin{array}{c}\text { Yogyakarta } \\
\text { (Non- } \\
\text { Migran) }\end{array}$ \\
\hline P8 & Perempuan & $\begin{array}{c}\text { Yogyakarta } \\
\text { (Non- } \\
\text { Migran) }\end{array}$ \\
\hline
\end{tabular}

keseluruhan tema yang dihasilkan dengan data 5) membaca seluruh transkrip secara berulang-ulang, 3) melakukan coding secara manual sesuai dengan pertanyaan penelitian, 4) mengaitkan tema-tema yang saling terkait, dan 5) menamai tema-tema yang ditemukan 6) menulis laporan penelitian. Kredibilitas dalam penelitian ini menggunakan triangulasi peneliti, yaitu melibatkan ahli untuk mengevaluasi penelitian dan juga melakukan inter-coding, yaitu berupa beberapa peneliti melakukan coding terhadap data-data yang diperoleh dan kemudian didiskusikan sehingga memperoleh tema atau konsep yang sesuai.

\section{HASIL}

\section{A. Alasan Memilih Teman}

Pada penelitian ini, alasan pemuda urban memilih teman cukup beragam, yaitu adanya gaya komunikasi yang sama, terciptanya iklim yang suportif, proksimitas, dan dapat terpenuhinya kebutuhan. 


\section{1) Gaya komunikasi yang sama}

Alasan ini hanya muncul pada pemuda migran dan mereka menjelaskan bahwa kesamaan ini terjadi karena adanya kecocokan antarindividu dan adanya kesamaan ketika menyampaikan sesuatu dengan terbuka, langsung dan jujur.

"Sebenernya suka orang yang to the point aja sih sebenernya. Blak - blakan gitu. Iya bilang iya, enggak bilang enggak"

\section{2) Terciptanya iklim yang suportif}

Alasan ini juga hanya muncul pada pemuda migran dan mereka menjelaskan bahwa mereka berteman dengan seseorang atau kelompok yang saling mendukung satu sama lain.

"karena dia memberi perhatiannya dia ke saya gitu lho mba.. jadi kayak eeh saya merasa diperhatikan, entah itu dalam bentuk mendengarkan pembicaraan."

\section{3) Proksimitas}

Berbeda dengan dua tema sebelumnya, tema ini hanya muncul pada pemuda nonmigran. Mereka menjelaskan bahwa mereka berteman dengan individu atau kelompok karena seringnya mereka bertemu di berbagai situasi.

\section{“...dengan siapapun itu lebih sering berinteraksi} pasti bakal temenan gitu."

\section{4) Terpenuhinya basic needs}

Tema ini muncul baik pada pemuda migran maupun nonmigran. Kebutuhankebutuhan tersebut adalah safety needs dan need for love and belonging. Walaupun jenis kebutuhan sama, tetapi terdapat perbedaan di dalamnya antara pemuda migran dan nonmigran. Safety needs yang muncul pada pemuda migran adalah kebutuhan informasi, bertahan hidup, dan networking, sedangkan pada pemuda nonmigran lebih bersifat relasional, yaitu kebutuhan informasi, networking, dan hiburan.

“...buat nambah silaturahmi aja sama orang lain, terus teman kan gak Cuma itu-itu aja. Tambah lagi, tambah wawasan, jadi nambah pengetahuan. Lebih luas lah."

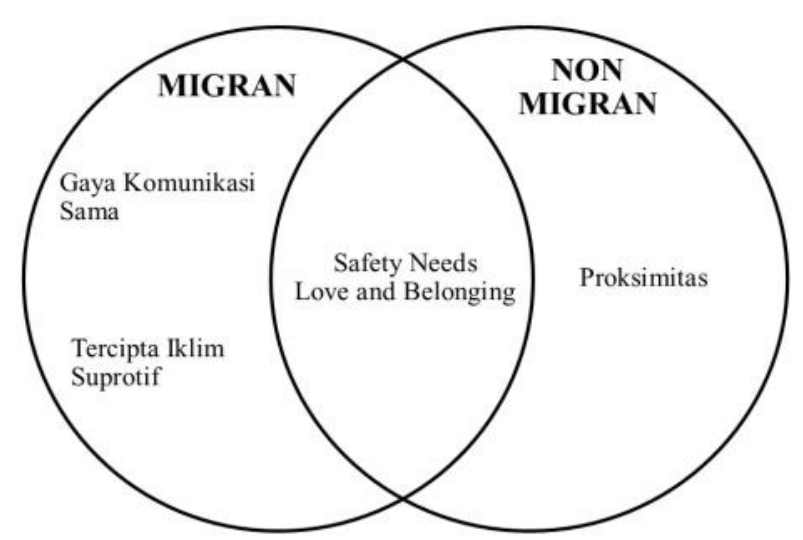

Diagram 1. Alasan Berteman

\section{B. Perubahan Pertimbangan Memilih Teman}

Temuan penelitian ini memunculkan tema mengenai perubahan pertimbangan dalam memilih teman pada beberapa partisipan, terlebih ketika partisipan berada pada lingkungan yang baru. Pertimbangan pertemanan tersebut mulanya berteman berdasarkan kecocokan, berteman untuk mendapat kesenangan, serta berteman hanya dengan orang dari daerah yang sama. Seiring waktu, partisipan merasakan adanya perubahan orientasi pertemanan.

Perubahan pertimbangan pertemanan dengan mempertimbangkan untung-rugi dalam berteman. Dalam hal ini jika seseorang dianggap memberikan kerugian untuknya, ia memilih untuk tidak berteman dengan orang tersebut.

“...kalau dulu tuh waktu masih jaman-jaman labil gitu malah, kita tuh bakal cenderungnya cuman cari temen yang asik aja, yang kayak bisa diajak seneng-seneng terus kayak yang penting bisa bahagia aja, tapi semakin ke sini kayak lebih nyarik temen itu yang bisa bikin kita lebih reflektif

Tabel 2. Partisipan yang mengalami perubahan alasan berteman

\begin{tabular}{|l|l|}
\hline \multicolumn{1}{|c|}{ Migran } & \multicolumn{1}{|c|}{ Non-migran } \\
\hline $\begin{array}{l}\text { Satu partisipan meng- } \\
\text { alami perubahan dan } \\
\text { tiga partisipan lainnya }\end{array}$ & $\begin{array}{l}\text { Tiga partisipan me- } \\
\text { ngalami perubahan } \\
\text { dan satu partisipan } \\
\text { tidak memiliki per- } \\
\text { ubahan pertimbangan } \\
\text { tidak memiliki per- } \\
\text { ubahan pertimbang- } \\
\text { an }\end{array}$ \\
\hline
\end{tabular}


sama diri sendiri, terus juga kayak gimana punya teman yang bisa membantu kita tuh, memfasilitasi aku buat bisa berkembang. "

\section{Jenis Pertemanan}

Partisipan pada penelitian ini membagi jenis-jenis pertemanan mereka berdasarkan kedalaman dan keintiman pertemanan mereka. Semakin dalam pertemanan mereka, semakin banyak sisi emosional yang diikatkan dalam pertemanan mereka.

\section{1) Pertemanan yang intim}

Jenis pertemanan ini adalah teman cerita dan teman dekat. Teman cerita adalah mereka yang menurut partisipan dapat dijadikan tempat untuk berkeluh kesah dan menjadi tempat bercerita, sedangkan teman dekat yaitu teman yang dirasa cocok dan nyaman satu sama lain.

"tempat curhat gitu, aku pasti baliknya ke temen-temenku yang bener-bener deket"

\section{2) Pertemanan yang biasa}

Jenis pertemanan ini termasuk teman biasa, teman yang didasarkan pada lingkungan, demografi, dan teman fungsional. Teman biasa adalah teman yang hanya sebatas kenal. Teman yang didasarkan pada lingkungan berupa teman $\mathrm{kerja} / \mathrm{kuliah}$, teman organisasi, dan teman dari significant others mereka. Teman yang didasarkan pada demografi ini dibedakan karena adanya perbedaan jenis kelamin, usia, dan daerah asal. Teman fungsional, yaitu pertemanan yang didasarkan pada pemenuhan kebutuhan tertentu dalam waktu singkat.

\begin{abstract}
"sejauh ini jenis pertemananku itu sebatas kenal saat kuliah atau kenal saat sekolah. Tapi, memang aku orangnya cenderung ramah gitu jadi nggak trus hanya ngobrolin urusan kuliah, urusan sekolah aja trus udah. Nggak nanya kabar pengen tau kesibukannya temen-temen apa gitugitu. Tapi nggak pernah berlanjut sampai yang sahabat banget yang sohib."
\end{abstract}

Jenis-jenis pertemanan tersebut semua muncul pada pemuda urban migran. Jenis pertemanan pemuda urban non-migran lebih sedikit daripada migran, yaitu teman fungsional tidak muncul pada pertemanan

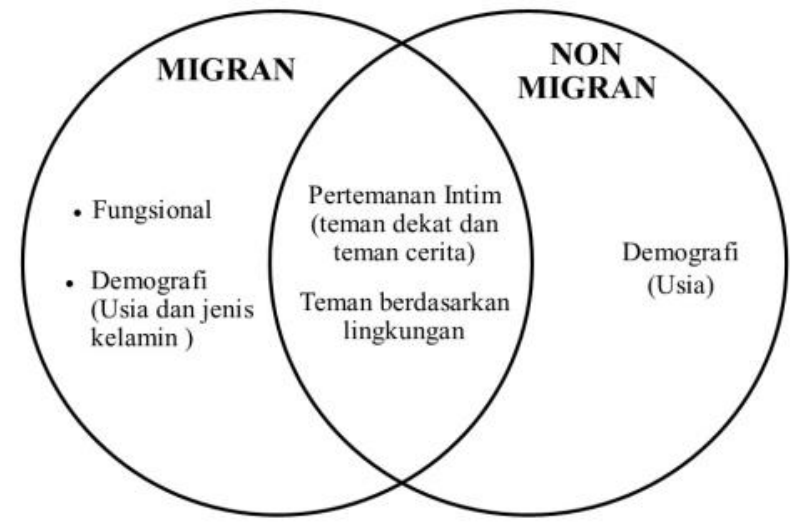

Diagram 2. Jenis Pertemanan

urban non-migran dan teman yang didasarkan pada demografi hanya membedakan berdasarkan daerah asalnya saja.

\section{PEMBAHASAN}

Penelitian ini bertujuan untuk menggambarkan pertemanan pemuda urban di Yogyakarta. Hasil penelitian ini menggambarkan bahwa motif pertemanan pemuda di antaranya adalah kesamaan gaya komunikasi, iklim pertemanan yang suportif, proksimitas, dan terpenuhinya kebutuhan. Pola kelompok-kelompok pertemanan yang dimiliki ternyata mengutamakan keintiman dalam berteman. Pemuda urban mengalami perubahan yang terletak pada orientasi berteman, yakni dari sekadar mendapat kesenangan bergeser menjadi mempertimbangkan manfaat dalam berteman.

Perubahan motif pertemanan dalam penelitian ini memiliki keterkaitan dengan pendapat Clark \& Mills (2012) yang menyebutkan bahwa masyarakat komunal tidak selalu menjalankan pertemanan secara intim. Pemuda di Yogyakarta merasa perlu adanya timbal balik atas pertemanan yang telah terjalin sekaligus mempertanyakan manfaat dari relasinya. Dengan kata lain, perubahan motif pertemanan memiliki nilai untung dan rugi di dalamnya.

Sifat budaya kolektivis yang komunal dan juga sifat daerah urban yang didasarkan pada pertukaran sosial muncul pada temuan penelitian ini. Konsep komunal menjelaskan bahwa pertemanan yang terjalin akan lebih dalam dan melibatkan emosi di dalamnya, 
sedangkan konsep pertukaran sosial menjelaskan bahwa pertemanan yang terjalin akan lebih menonjolkan adanya manfaat yang diberikan tanpa melibatkan ikatan emosional (Clark \& Mills, 2012). Dalam temuan ini pun pemuda urban di Yogyakarta memiliki jenis pertemanan seperti pada pertemanan yang muncul pada kedua konsep tersebut. Jenis tersebut adalah pertemanan intim yang memiliki ikatan emosional di dalamnya dan pertemanan biasa yang mengedepankan adanya timbal balik. Gaya komunikasi yang sama menjadi salah satu motif pemuda urban di Yogyakarta untuk berteman. Hal ini berbeda dengan penelitian yang dilakukan oleh Gompers, et al. Smith, et al. dan Leszczensky \& Pink $(2016$; 2015; 2016) yang menjelaskan bahwa pertemanan dapat terbentuk karena adanya kesamaan etnis yang dimiliki. Kesamaan gaya komunikasi ini mencakup bahan obrolan, humor, dan gagasan yang dimiliki masing-masing partisipan. Mereka cenderung memiliki hubungan yang hidup ketika memiliki gaya komunikasi yang sama. Etnis atau identitas sosial yang melekat pada diri individu tidak menjadi hal yang diutamakan dalam membentuk pertemanan karena ketika mereka merasa bahwa mereka memiliki gaya komunikasi yang sama walaupun berasal dari etnis yang berbeda, mereka masih dapat menjalin pertemanan. Hal ini menandakan bahwa terdapat fleksibilitas pertemanan di Yogyakarta.

Kecenderungan individu untuk memilih teman dengan dasar kesamaan disebabkan oleh adanya seleksi sosial. Partisipan mengalami proses memilih individu lain yang serupa dengan mereka, seperti gagasan, gaya komunikasi, dan gaya hidup. Hasil tersebut berbeda dengan penelitian de Klepper et al. (2010) dalam konteks militer. Mereka menemukan bahwa pengaruh sosial dapat mendorong timbulnya pertemanan. Motif pertemanan tidak didasarkan pada kemiripan, namun lebih pada adanya pengaruh sosial melalui kegiatan-kegiatan kedisiplinan. Anggota militer memiliki kesempatan yang sedikit untuk memilih teman berdasarkan preferensi masing-masing. Pada penelitian ini, partisipan mampu dan memiliki peluang untuk melakukan seleksi. Hal ini dibuktikan dengan perbedaan kelompok-kelompok pertemanan yang dimiliki.

Interaksi yang hidup juga dapat memunculkan iklim komunikasi yang suportif. Penelitian ini menemukan adanya iklim suportif terbentuk ketika adanya ketersediaan untuk berdiskusi dan pertemanan yang dapat mendorong partisipan untuk mengembangkan diri. Hal ini termasuk dalam value of rewards, yaitu rewards yang dipersepsikan secara personal oleh masingmasing individu (Redmond, 2015). Banyak aspek yang dapat dipersepsikan sebagai rewards. Dalam penelitian ini, kesediaan yang ditawarkan teman partisipan dipersepsikan sebagai rewards, sehingga pertemanan yang dimiliki dapat memberikan dukungan bagi individu (Wang et al., 2014).

Pertemanan yang dimiliki partisipan juga memungkinkan didapatkannya social rewards. Social rewards merupakan rewards yang hanya dapat diraih melalui interaksi dengan orang lain (Redmond, 2015). Interaksi umum tanpa ikatan emosional dan bersifat timbal balik dapat memunculkan rewards. Terlebih pada relasi pertemanan yang melibatkan melibatkan emosi dan tindakan sukarela, rewards yang didapatkan semakin bermakna. Pada penelitian ini, pertemanan mampu memenuhi kebutuhan dasar, yakni safety needs dan love and belonging. Pertemanan yang dimiliki memunculkan perasaan aman dan memiliki ikatan dengan tempat yang baru. Hal tersebut sesuai dengan teori piramida kebutuhan Maslow, yaitu pertemanan merupakan ekspresi dari kebutuhan kasih sayang (Schultz \& Schultz, 2009). Periode dewasa awal merupakan masa untuk mengalami transisi kehidupan. Partisipan menjalani transisi ini di tempat yang baru. Hal tersebut tentu semakin mendorong individu untuk memiliki kebutuhan belonging yang tinggi. Selain itu, terpenuhinya kebutuhan 
tersebut melalui hubungan pertemanan dapat menurunkan perasaan rentan terhadap perasaan rendah diri (Xie et al., 2018).

Penelitian lain sebelumnya menjelaskan bahwa pemuda Yogyakarta lebih memilih memiliki banyak teman di berbagai tatanan sosial dan jaringan sosial yang luas tanpa memperhatikan keintiman pertemanan tersebut (Dewi \& Minza, 2018). Penelitian ini menemukan bahwa pertemanan pada pemuda urban migran dan non-migran ternyata juga lebih beragam pada jenis pertemanan yang biasa, seperti pertemanan berdasarkan lingkungan, demografi, dan fungsinya. Hal ini menunjukkan bahwa pemuda urban di Yogyakarta lebih mementingkan pertemanan biasa di berbagai tatanan sosial dan jaringan sosial mereka daripada pertemanan yang intim.

Temuan yang membedakan dengan temuan sebelumnya adalah pemuda urban migran memiliki jenis pertemanan biasa yang lebih banyak daripada pemuda urban nonmigran. Pemuda urban migran memiliki jenis teman berdasarkan demografi (jenis kelamin dan usia) sedangkan pada nonmigran, pertemanan berdasarkan usia tidak muncul. Budaya Jawa dapat mempengaruhi tatanan sosial di masyarakat, yaitu individu yang memiliki usia lebih tua atau memiliki kedudukan sosial lebih tinggi harus dihormati (Heuser \& Brandt, 2011). Hal ini lah yang memungkinkan pemuda urban non-migran tidak memiliki jenis pertemanan berdasarkan usia karena menganggap individu yang lebih tua sebagai individu yang memiliki kedudukan lebih tinggi sehingga harus dihormati.

Banyaknya jenis pertemanan yang muncul pada pemuda migran juga dapat didasarkan pada karakteristik pemuda urban migran itu sendiri. Karakteristik pemuda urban adalah cenderung ingin membangun identitasnya sehingga memiliki keinginan untuk mengeksplorasi tempat baru yang menentukan bentuk pertemanannya juga (Barratt et al., 2012). Hal itu memungkinkan pemuda urban migran lebih banyak berinteraksi dengan individu yang berbedabeda, sehingga menjadikannya memiliki pertemanan yang beragam. Penelitian ini sejalan dengan penelitian Kathiravelu \& Bunnel (2017) yang menjelaskan bahwa adanya perbedaan identitas sosial tidak mempengaruhi terjalinnya komunikasi dalam pertemanan sehingga memungkinkan pemuda migran memiliki variasi perbedaan identitas sosial dengan temannya.

Jenis pertemanan pada pemuda urban nonmigran cenderung bersifat communal sharing karena ada perasaan saling memiliki satu sama lain (Haslam, 2004). Perasaan saling memiliki tersebut terlihat pada jenis pertemanan teman dekat dan teman cerita. Individu memiliki ikatan emosional, saling bercerita dan memberikan solusi. Pemuda urban migran pun memiliki jenis pertemanan yang intim seperti pada pemuda nonmigran, tetapi pemuda urban migran cenderung lebih banyak memiliki jenis pertemanan pada jenis pertemanan yang biasa. Hal ini dikarenakan pertemanan pemuda urban migran cenderung bersifat untung rugi seperti adanya pertukaran informasi dan companion (Haslam, 2004).

Pada penelitian ini, pemuda urban membagi jenis pertemanan berdasarkan keintiman hubungan, yaitu teman biasa dan teman dekat. Partisipan menjalin hubungan dengan teman biasa sebagai wujud ramah tamah, sedangkan pada teman dekat partisipan dapat memenuhi kebutuhan emosionalnya. Hal tersebut sesuai dengan penelitian Way et al. (2005) yang menjelaskan bahwa teman dekat adalah teman yang memiliki ikatan emosional lebih dalam dari teman jenis lainnya. Heuser \& Brandt (2011) juga mengemukakan bahwa teman biasa dipandang sebagai figur yang membantu dalam urusan praktis, sedangkan teman dekat dapat membantu individu untuk memenuhi ekspresi kebutuhan individu. Tidak menutup kemungkinan taraf intimasi teman dekat melebihi kedekatan keluarga.

Pertemanan biasa memiliki variasi yang lebih banyak daripada jenis pertemanan 
intim. Jenis pada pertemanan ini adalah teman biasa, teman yang didasarkan pada lingkungan, demografi, dan teman fungsional. Teman jenis ini tidak memiliki ikatan emosional yang dalam seperti teman cerita dan teman dekat. Pemuda urban memiliki teman yang lebih banyak pada jenis ini. French et al. (2006) menjelaskan bahwa pemuda di Indonesia dan Korea Selatan lebih banyak memiliki pertemanan yang tidak intim dan cenderung memiliki pertemanan yang luas. Mengingat pemuda urban lebih banyak terlibat pada pertemanan jenis ini daripada pertemanan yang lebih dalam lagi.

Penelitian ini memiliki implikasi yaitu pentingnya mengetahui motif-motif pembentuk pertemanan pada individu yang berada pada daerah dengan keberagaman dapat menjadi salah satu dasar akademik faktor penguat untuk pemersatu bangsa dan juga meminimalkan konflik pertemanan yang mungkin timbul. Selain itu, dengan mengetahui jenis-jenis pertemanan yang muncul pada pemuda urban, maka dapat mengetahui pula perbedaan-perbedaan yang melekat karena mereka membedakan jenis pertemanan berdasarkan perbedaan yang melekat pada teman-temannya.

Penelitian ini masih memiliki limitasi, yaitu terletak pada jumlah partisipan yang belum representatif dan asal daerah pemuda urban yang hanya dari Jabodetabek, sehingga kedua hal tersebut dapat dipertimbangkan dan disempurnakan pada penelitian selanjutnya.

Keberagaman yang ada pada daerah urban ternyata tidak menghalangi pemuda untuk membangun hubungan pertemanan. Hal ini memungkinkan adanya toleransi terhadap perbedaan yang ada sehingga mereka akan tetap menjalin relasi dengan orang lain. Respon pemuda urban terhadap perbedaan merupakan hal yang perlu digali lebih lanjut agar dapat mengetahui hal-hal yang dapat ditoleransi untuk menjalin pertemanan. Pentingnya mengetahui adanya toleransi juga dapat menjadi salah satu cara untuk mempererat persatuan.

\section{KESIMPULAN}

Penelitian ini menemukan alasan dan jenis pertemanan pemuda urban di Yogyakarta. Alasan pemuda urban di Yogyakarta berteman adalah adanya gaya komunikasi yang sama, terciptanya iklim yang suportif, serta dapat terpenuhinya basic needs. Seiring berjalannya waktu, partisipan melibatkan dampak positif atau negatif yang ditimbulkan untuk dipertimbangkan dalam berteman.

Jenis pertemanan yang muncul pada pemuda urban adalah teman yang intim dan teman biasa. Teman yang intim, yaitu teman dekat dan teman cerita, serta teman biasa yang didasarkan pada lingkungan dan didasarkan pada usia muncul pada pemuda urban baik migran maupun nonmigran. Pada jenis teman biasa yang berdasarkan fungsi dan jenis kelamin hanya muncul pada pemuda urban migran.

\section{DAFTAR PUSTAKA}

Barratt, C., Mbonye, M., \& Seeley, J. (2012). Between town and country: Shifting identity and migrant youth in Uganda. The Journal of Modern African Studies, 50(2), 201-223. https:// doi.org/10.1017/S0022278X1200002X

Braun, V., \& Clarke, V. (2006). Using thematic analysis in psychology. Qualitative Research in Psychology, 3 (2), 77-101. https:// doi.org/10.1191/1478088706qp063oa

Campbell, K., Holderness, N., \& Riggs, M. (2015). Friendship chemistry: An examination of underlying factors. The Social Science Journal, 52(2), 239$247 . \quad \mathrm{https}: / /$ doi.org/10.1016/ j.soscij.2015.01.005

Clark, M. S., \& Mills, J. (2012). A theory of communal (and exchange) relationships. In P. A. M. V. Lange, A. W. Kruglanski, \& E. T. Higgins (Eds.), Handbook of theories of social psychology (Vol. 2, pp. 232-250). SAGE. 
Corsano, P., Musetti, A., Caricati, L., \& Magnani, B. (2017). Keeping secrets from friends: Exploring the effects of friendship quality, loneliness and selfesteem on secrecy. Journal of Adolescence, 58, 24-32. https:// doi.org/10.1016/ j.adolescence.2017.04.010

de Klepper, M., Sleebos, E., van de Bunt, G., \& Agneessens, F. (2010). Similarity in friendship networks: Selection or influence? The effect of constraining contexts and non-visible individual attributes. Social Networks, 32(1), 82$90 . \quad$ https://doi.org/10.1016/ j.socnet.2009.06.003

Dewi, S. T., \& Minza, W. M. (2018). Strategi Mempertahankan Hubungan Pertemanan Lawan Jenis pada Dewasa Muda. Gadjah Mada Journal of Psychology (GamaJoP), 2(3), 192-205$205 . \quad \mathrm{https}: / /$ doi.org/10.22146/ gamajop.36946

Echols, L., \& Graham, S. (2016). For Better or Worse: Friendship Choices and Peer Victimization Among Ethnically Diverse Youth in the First Year of Middle School. Journal of Youth and Adolescence, 45(9), 1862-1876. https:// doi.org/10.1007/s10964-016-0516-0

French, D. C., Bae, A., Pidada, S., \& Lee, O. (2006). Friendships of Indonesian, South Korean, and U.S. college students. Personal Relationships, 13(1), 69-81. https://doi.org/10.1111/j.14756811.2006.00105.x

Gompers, P. A., Mukharlyamov, V., \& Xuan, Y. (2016). The cost of friendship. Journal of Financial Economics, 119 (3), 626-644. https://doi.org/10.1016/ j.jfineco.2016.01.013

Hafen, C. A., Laursen, B., Burk, W. J., Kerr, M., \& Stattin, H. (2011). Homophily in stable and unstable adolescent friendships: Similarity breeds constancy. Personality and Individual
Differences, 51(5), 607-612. https:// doi.org/10.1016/j.paid.2011.05.027

Haslam, N. (Ed.). (2004). Relational Models Theory: A Contemporary Overview (1 edition). Psychology Press.

Heuser, E. A., \& Brandt, A. (2011). Friendship and socio-cultural context: Experiences from New Zealand and Indonesia. In B. Descharmers, E. A. Heuser, T. Loy, \& C. Krüger, Varieties of friendship: Interdisciplinary prespectives on social relationships (pp. 145-174). V\&R Unipress.

Hildayah, K. (2019, January 25). Tercatat 11.923 Penduduk Baru di Kota Yogya Selama 2018-Tribun Jogja. TribunJogja.com. https:// jogja.tribunnews.com/2019/01/25/ tercatat-11923-penduduk-baru-di-kotayogya-selama-2018

Kathiravelu, L. (2013). Friendship and the urban encounter: Towards a research agenda. MMG Woriking Paper, 13-10.

Kathiravelu, L., \& Bunnell, T. (2017). Introduction: Urban friendship networks: Affective negotiations and potentialities of care. Urban Studies, 55 (3), 491-504. https:// doi.org/10.1177/0042098017737281

Killias, O. (2017). Distant friends and intimate strangers: On the perils of friendship in a Malaysian apartment building. Urban Studies, 55(3), 554569. https:// doi.org/10.1177/0042098017714931

Leszczensky, L., \& Pink, S. (2015). Ethnic segregation of friendship networks in school: Testing a rational-choice argument of differences in ethnic homophily between classroom- and grade-level networks. Social Networks, 42, 18-26. https://doi.org/10.1016/ j.socnet.2015.02.002

Lobo, M. (2017). Re-framing the creative city: Fragile friendships and affective art spaces in Darwin, Australia. Urban 
Studies, 55(3), 623-638. https:// doi.org/10.1177/0042098016686510

Nguyen, A. W., Chatters, L. M., Taylor, R. J., \& Mouzon, D. M. (2016). Social Support from Family and Friends and Subjective Well-Being of Older African Americans. Journal of Happiness Studies, 17(3), 959-979. https:// doi.org/10.1007/s10902-015-9626-8

Redmond, M. V. (2015). Social Exchange Theory (p. 36) [English Technical Reports and White Papers]. Iowa State University.

Rubin, K. H., \& Bowker, J. C. (2018). Friendships. In M. Bornstein (Ed.). In The SAGE encyclopedia of lifespan human development (pp. 908-910). SAGE Publications, Inc. 10.4135/9781506307633.n339

Schultz, D. P., \& Schultz, S. E. (2009). Theories of personality (9th ed). Wadsworth Cengage Learning.

Smith, S., McFarland, D. A., Van Tubergen, F., \& Maas, I. (2016). Ethnic Composition and Friendship Segregation: Differential Effects for Adolescent Natives and Immigrants. American Journal of Sociology, 121(4), 1223-1272. https:// doi.org/10.1086/684032

Triandis, H. C. (2018). Individualism And Collectivism (1st edition). Routledge. https://doi.org/10.4324/9780429499845

Tsaousis, I. (2016). The relationship of selfesteem to bullying perpetration and peer victimization among schoolchildren and adolescents: A meta -analytic review. Aggression and Violent Behavior, 31, 186-199. https:// doi.org/10.1016/j.avb.2016.09.005

Wang, M. L., Pbert, L., \& Lemon, S. C. (2014). Influence of family, friend and coworker social support and social undermining on weight gain prevention among adults: Support and social undermining on weight gain prevention. Obesity, 22(9), 1973-1980. https://doi.org/10.1002/oby.20814

Way, N., Gingold, R., Rotenberg, M., \& Kuriakose, G. (2005). Close friendships among urban, ethnic-minority adolescents. New Directions for Child and Adolescent Development, 2005 (107), 41-59. https://doi.org/10.1002/ cd. 120

Xie, X., Wang, Y., Wang, P., Zhao, F., \& Lei, L. (2018). Basic psychological needs satisfaction and fear of missing out: Friend support moderated the mediating effect of individual relative deprivation. Psychiatry Research, 268, 223-228. https://doi.org/10.1016/ j.psychres.2018.07.025 